\title{
Disgorgement as Remedial Action in Indonesian Capital Market Regime*
}

\author{
Uni Tsulasi Putri ${ }^{1}$ \\ ${ }^{1}$ Faculty of Law, Universitas Ahmad Dahlan, Indonesia \\ uni.putri@law.uad.ac.id \\ * This article reflects the position of law as on January 26, 2020
}

\begin{abstract}
Introduction to The Problem: Financial Services Authority introduced the disgorgement within the field of Indonesian Capital Market by the establishment of OJK Regulation Draft concerning Disgorgement and Disgorgement Fund in the Capital Market in 2019. Disgorgement itself is a very new concept in Indonesia. It is meant to be a remedial action. Furthermore, it is expected to prevent the Party for the enjoyment of illegal profit, compensate for the victim's loss, and to contain the corrective element. It also acts as a deterrence effect.
\end{abstract}

Purpose/Objective Study: This study aims to study on how the disgorgement as remedial action would be applied and create a deterrence effect in the Indonesian Capital Market Regime.

Design/Methodology/Approach: This is normative legal research that uses a qualitative research method. This study conducted a literature review and comparative study with disgorgement regulation within in respect of securities law in common law and civil law jurisdiction.

Findings: In the upcoming disgorgement technical manner, OJK will give a written order for the Party who violate capital market regulation and pursuing illegally obtained profit or illegally avoided loss to return sum amount of money sum up with interest (if any). To uphold this scheme, Indonesia needs to develop a theoretical framework such as actio de in rem verso or unjust enrichment. Furthermore, to create a deterrence effect, Indonesia shall provide adequate, proportionate, and dissuasive sanctions.

Paper Type: Research Article.

Keywords: Disgorgement; Remedy; Capital Market; Investor.

\section{Introduction}

Capital Market becomes one of the choices for people to invest their money with an expectation to gain profit in the future. It is a symbol of the modern economy as well as being a crucial factor in national economic development. There are two substantial functions of the capital market: economic and financial function. The former means that the capital market becomes the facility where investors and securities companies can meet and bridge both parties' interests. The latter means, investors may receive the sum of profits from the investment they made (Muklis, 2016). 


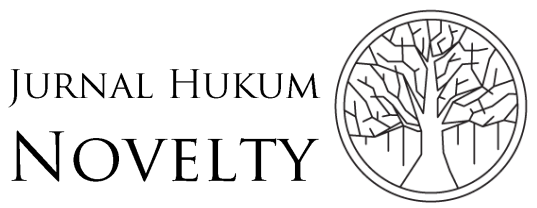

Volume 11, Issue 01, 2020, pp. 01-13
P-ISSN: $1412-6834$

E-ISSN: 2550-0090

In Indonesia, the capital market plays a vital role in the national economic growth. It has been operated since August 10,1977. The latest weekly statistical report issued by Financial Services Authority (hereinafter OJK), in the fourth week (23 $3^{\text {rd }}-27^{\text {th }}$ ) of December 2019, showed that the stock market index in 2019 reached 6.329, 21. There were 668 listed companies. The daily trade average was 15.014,46 million stock as amount as 9.1222,66 billion rupiahs (OJK, 2019b).

The more develop the economy is, the more advance the violation might be, including in the capital market. Since the first launch of capital market, there are numbers of violation cases. In 2017, there was the case of Esther Pauli Larasati, PT Reliance Securities Tbk, PT Magnus Capital and other related parties. In the same year, OJK issued an announcement of administrative sanction towards those related parties who conduct violation of capital market. OJK imposed Business License Revocation on PT Magnus Capital as Broker Dealer and Underwriter. The revocation was on the ground of, inter alia, PT Magnus Capital lent its bank accounts in PT Bank Mandiri (Persero) Tbk and PT Bank Central Asia Tbk to Esther Pauli Larasati. The lending itself was not part of Underwriter or Broker Dealer activities. OJK also imposed monetary penalty on PT Reliance Securities Tbk for IDR 500 million and Written Order to pay the transaction fee derived from the clients for IDR 5 billion. Towards Esther Pauli Larasati herself, the District Court of West Jakarta had imposed penal sanction of 2,5 years imprisonment (OJK, 2017).

The latest issue and still ongoing involves an insurance company, Jiwasraya. There has been a suspicious market manipulation, i.e., wash trade following the corruption case of Jiwasraya. Recently, OJK requests Indonesian Central Securities Depository to blocks around 800 securities accounts. The blockade was following the corruption case and default of Jiwasraya (Tri, 2020).

In 2008, Signature Capital Indonesia sold the repo, and the warrant belongs to the clients without their permission. The total loss allegedly reached IDR 101, 69 billion. In 2009 Sarijaya Sekuritas conducted embezzlement, which allegedly causes the loss of around 8700 clients. In 2015, PT Sekawan Intipratama Tbk was default and performed market manipulation. This latter involved Reliance Securities, Danareksa Sekuritas, and Millenium Danatama Sekuritas. The total loss achieved IDR 300 - 400 billion.

In responding to several cases of capital market violation, 0JK preferably chose the administrative means by imposing the sanction of fine or charging a sum of compensation. Based on the research conducted by Pakpahan Cs., OJK's role to prevent capital market crime needs an enhancement as a capital market crime might be minimized (Sianipar, 2019). Furthermore, the essential purpose of strengthening OJK's role is investor protection in nowadays risk society era. Ulrich Beck, a sociologist from German, asserted that risk society is the condition where the 
community faces a threat and uncertainty of life, which happened in the developed industry society (Akbar, 2016; Boyd, Beck, \& Shrader-Frechette, 1993; Putranto, 2017).

As time goes by, in March 18, 2019, 0JK took a step ideally to solve the problem above. In order to secure the investors' loss, OJK established the Draft of OJK Regulation concerning Disgorgement and Disgorgement Fund in the Capital Market. OJK then asked for a response from the experts and public society towards the OJK Regulation Draft until March 29, 2019 (OJK, 2019a). In the general explanation of the Draft paragraph 2, it mentions that "Disgorgement as a remedial action is expected to prevent Party conducting a violation of enjoyment of illegally obtained profits, compensate the loss of the victims, it has corrective characteristic and is expected to impose deterrence effect." OJK firmly asserted that the disgorgement concept brought in the OJK would be the remedial action (Mentari, 2019).

In Indonesia, disgorgement is still at the infancy stage. Moreover, it is not peculiar in the civil law system as compared to the common law jurisdiction. Therefore, this study aims to examine on how the disgorgement as remedial action would applied create a deterrence effect within Indonesian Capital Market Regime. As disgorgement is a very new idea brought in Indonesia, to discuss the main topic, this paper would make a comparative study in the theoretical and the legal basis framework to other civil law and common law jurisdictions.

\section{Methodology}

The paper is normative legal research, which uses a qualitative research method. This study conducted a literature review of the capital market regulations as well as the OJK Regulation Draft concerning Disgorgement and Disgorgement Fund. Furthermore, this study also involved comparative study with the notion of disgorgement within the securities law of the United States, Netherlands, Romania, Belgium, China, and France. The data used in this article is secondary data, which consists of primary legal sources and secondary legal sources. Primary legal sources are, inter alia, the Act Number 8 of 1995 on Capital Market, Securities Exchange Act of 1934, Securities Act of 1933, Sorbanes-Oxley of 2002, Statute of Limitation, Texas Gulf-Sulphur v. SEC, Kokesh v. SEC, Securities Law of People's Republic of China, Trust Law of the People's Republic of China, Law of the People's Republic of China on Funds for Investment in Securities, as well as Dutch, Romanian, French and Indonesian Civil Code. The secondary legal sources used in this research are journals, books, and other supporting documents related to the disgorgement.

\section{Results and Discussion}

\section{Disgorgement in Indonesian Capital Market Law and Its Comparative Study}

Based on the Act Number 8 of 1995 concerning Capital Market jo. Act Number 21 of 2011, it shows that OJK has the authority to establish and enforce the rules on disgorgement. Article 3 section (1) Capital Market Law mentions that the guidance, 
regulation, and day-to-day supervision of the capital market shall be provided by the Capital Market Supervisory Agency (as referred to as BAPEPAM). Furthermore, article 5 letter $\mathrm{n}$ mentions, BAPEPAM shall take necessary means to avert loss to the public arising from the violation of Capital Market Regulations. Since December 31, 2012, a year after the enactment of the Act Number 21 of 2011 on Financial Services Authority, based on article 55, the ruling and supervisory function, duty and authority of BAPEPAM was transferred to OJK.

Mentari argued in her thesis that $0 \mathrm{JK}$ normatively has the authority to issue and enforce the disgorgement rules. Additionally, OJK's function as the capital market authority has similarities in some other countries, inter alia: (1) rulemaking function as quasi-legislative power; (2) adjudicatory function as quasi-judicial power; and (3) investigatory-enforcement function as 'special police' (Mentari, 2019). In this case, $\mathrm{OJK}$, as quasi-legislative power, tried to strengthen capital market enforcement, which may create a deterrence effect (OJK, 2019b).

\section{Defining Disgorgement}

According to Black's Law Dictionary, disgorgement is "the act of giving up something (such as profits illegally obtained) on-demand or by legal compulsion" (Garner, 2009). The court can order the wrongdoer to pay back illegally-obtained profits to prevent unjust enrichment (actio de in rem verso). This notion of disgorgement is picturized in American rhetoric, "A person is not permitted to profit by his own wrong." It is in line with the well-known statement in Jegon v Vivian (1870-1871), as Lord Hatherly stated before the Chancery Appeal, "This Court never allows a man to make a profit by a wrong." Even though it is an ideal statement, the legal reality might look different. There is no real understanding of disgorgement in all over the countries as there is a matter of different terminology (Hondius \& Jenssen, 2015b). Furthermore, each jurisdiction has its own recognition on which branch of law the disgorgement should be charged and what instrument shall apply.

In Indonesia, the concept of disgorgement is very infant. The first introduction of disgorgement was in the issuance of the OJK Draft Regulation on the Disgorgement and Disgorgement Fund in March 2019. In this Draft, the term "disgorgement" was defined as "the means taken by OJK to give order to the Party who conducts violation towards the regulation within the field of capital market to return a sum of illegallyobtained profit or illegally-avoided loss" (OJK, 2019b). OJK will determine the disgorgement amount as maximum as the illegal-gained profit or illegal-avoided loss by the Party who conduct a violation of capital market regulation added up with the disgorgement interest (if any).

In the general explanation of the Draft paragraph 2, it mentions that "Disgorgement as a remedial action is expected to prevent Parties conducting a violation of enjoyment of illegally obtained profits, compensate the loss of the victims, it has the corrective characteristic, and is expected to impose deterrence effect." OJK firmly 
asserted that the disgorgement concept brought in the OJK would be the remedial action. The other "disgorgement" terminology used under OJK Regulation Draft is "disgorgement fund." The latter was defined as, "fund which is collected from the imposition of disgorgement to the Party who conducts violation of regulation within the field of the capital market for administration and distribution to the Party suffering loss due to the violation, and the Party suffering loss in question has submitted the claim within the predetermined period." OJK may form a disgorgement fund when the collected fund from the imposition of disgorgement is adequate enough. OJK will establish a "disgorgement fund" in case the collectible "disgorgement fund" is feasible or cost-efficient (OJK, 2019a).

Even though OJK has firmly asserted that disgorgement would act as a remedial action, the challenges to disgorgement enforcement would come forward. In its former practical State -US, the notion of disgorgement faced an alteration from "remedy" to the "penalty," which put a consequence to the five-year limitation period. (See the elaboration in the next sub-subdiscussion). Hence, a similar problem has unavoidably happened in Indonesia, even though it requires further analysis of the difference between "remedy" and "penalty" in civil law.

Under Black's Law Dictionary, remedy, as referred to as civil remedy, is, "the means of enforcing a right or preventing or redressing a wrong; legal or equitable relief." It has a different meaning with remedial action, which also termed as personal action. The latter means "an action brought for the recovery of debts, personal property, or damages arising from any cause" (Garner, 2009). Based on the Handbook of CommonLaw Pleading by Shipman (1923), the most common personal action is brought for the recovery of a debt, covenant, assumpsit, detinue, trespass, trespass on the case, trover, and replevin. Indeed, both the concept of "remedy" as well as "remedial action" is very well known in common law. Thus, the establishment of disgorgement within Indonesian civil legal system shall be strengthened by the theoretical framework of disgorgement.

When the rules concerning disgorgement have been established in the level of OJK Regulation, the next question is whether OJK has the authority to impose disgorgement and collect the disgorgement fund? Whether the OJK Act, as well as the Capital Market Act, are enough as a legal basis to establish the authority of OJK to impose disgorgement and collect the disgorgement fund? Whether disgorgement order is enough to put under OJK Written Order? Whether disgorgement rules are necessary to be asserted in an act level of regulation?

Indonesia is now on the process of revising the 1995 Capital Market Law, involving the disgorgement and disgorgement fund as investors' protection to be one of the subject matter in the upcoming Bills (Tari, 2019). However, the process of revision or amendment of the law takes an extended period. The establishment of OJK Regulation on Disgorgement and Disgorgement Fund probably will be the best solution, prior to 


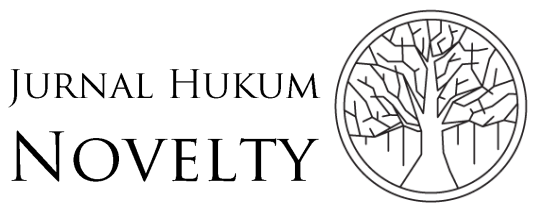

Volume 11, Issue 01, 2020, pp. 01-13
P-ISSN: $1412-6834$

E-ISSN: 2550-0090

the amendment of Capital Market Law. Despite that, Indonesia shall be ready to face the future challenge on the enforcement of disgorgement, especially on the ground theory basis of its establishment, moreover, its implementation. In fact, for now, it is challenging to find the sources of disgorgement and its theoretical framework in Indonesian literature.

In the United States of America, the idea of disgorgement has been evolved and altered. Previously, the Securities Exchange Act 1934 did not include disgorgement in any separate statutory provision. The first notion of disgorgement was in Securities Exchange Commission v. Texas Gulf Sulphur Co. in 1971, the court concluded that disgorgement is inherently an ancillary equitable remedy. In 1990, the US Congress granted the remedy of disgorgement in the Security Enforcement Remedies and Penny Stock Reform Act 1990 (Ryan, 2013). Since then, for fifty years, SEC had been obtaining the disgorgement as the remedy in numerous cases (Karmel, 2018), particularly within the securities fraud as well as insider trading regime (Shah, 2019).

Recently, the notion of disgorgement was thrown into question. The question was related to the purpose of the Statute of Limitation, which provides, "any action, suit or proceeding for the enforcement of any civil fine, penalty, or forfeiture shall subject to the five-year limitations." In SEC v. Kokesh, 2017, SEC argued that disgorgement is a remedy which is not subject to the statute of limitation. Surprisingly, the Supreme Court rejected the argument and held that disgorgement is a penalty and therefore falls within the five-year limitations period (Kirk, 2015; Ryan, 2013). The Supreme Court established two parameters to define a penalty-based sanction. First, the court determined that the question shall be whether the misconduct is redressed to the public or the individual. In SEC v. Kokesh, the court agreed that the remedy was sought for a violation conducted against the US and not an individual. Second, the court addressed that a penalty sanction is found for punishment and to give deterrence in offending the future like-manner, in contrast to the compensation. The court explained that SEC's disgorgement has punitive purposes, and its primary purpose is deterrence, and deterrence is "inherently punitive" (Latham \& Watkins, 2017; Ryan, 2013; Shah, 2019). Therefore, after the Supreme Court Decision in SEC v. Kokesh, the notion of disgorgement was altered from being as "equitable remedy" to the "penalty" in more of punitive sense.

\section{Disgorgement Theoretical Framework}

It almost a common knowledge that the initial case of disgorgement correlates to the unjust enrichment theory. The primary rationale of this theory is when a Party's gain, which is not due to legal cause resulted the loss of other Party, then the Party with the profit is under a legal obligation to return all of the gain (Gao \& Liu, 2015). The first case of unjust enrichment was found in the intellectual property law case as a socalled "Ariston" case back in 1895. Acting as the defendant, Ariston, a company producing a mechanical music player in which a rolling tape played different songs. One of the songs was composed by the claimant but was not well known at that time. 
Ariston achieved great success in playing the claimant's song. The problem was the song had been used without a license from the claimant. The case was then decided by Reichsgericht before the Bürgerliches Gesetzbuch (German Civil Code, hereinafter as referred to as BGB) entered into force (Danneman, 2009). The court held that the violation of such rights opens three different and alternatives opportunities. First, the claimant may seek compensation for the loss suffered from the violation. Second, in case there is no loss, he may claim for the amount of money that the defendant would reasonably have paid to acquire rights of publication. Third, he may request for the defendant to pay all of the benefits originated from the usage of a patented good without authorization (Giglio, 2001). The latter was meant that he might claim an account of profits that he need not show any suffered loss.

In responding to unjust enrichment theory, JGA Linssen, an advocate in the Netherlands whose doctoral thesis was regarding unjustified enrichment, considered unjust enrichment to be a better ground for disgorgement (Hondius \& Janssen, 2015a; Linssen, 2001; Schauer \& Verschraegen, 2017). The Netherlands would likely be the best example of its general legal basis of disgorgement. In the Netherlands Civil Code 1992, article 6:104 on the estimation of damage and the handing over of profits provides:

"If someone, who is liable towards another person based on tort or default of complying with an obligation, has gained a profit because of this tort or nonperformance, then the court may, upon the request of the injured person, estimate that damage in line with the amount of this profit or a part of it."

Even though, in Waeyen-Scheers v. Naus case, the Dutch Supreme Court concluded that the provision is only as a means to assess damages and not an independent and specific remedy for disgorgement damages (Hondius \& Janssen, 2015b).

Under Romanian Civil Code 2009, which entered into force on October 1, 2011, the recovery disgorgement of profits/damages mechanism is available but limited to actio de in rem verso. Under the Roman and Civil law term, action(n) de in rem verso means:

"An action for unjust enrichment, in which the plaintiff must show that enrichment was bestowed, that the enrichment caused an impoverishment. That there is no justification for the enrichment and impoverishment, and that the plaintiff has no other adequate remedy at law, including no remedy under an express or implied contract" (Garner, 2009).

In the Romanian legal system, this action requires factual and legal circumstances as the ground of applicability. The former shall cover the enrichment of the defendant's asset, the impoverishment of the claimant's asset, and a connection between both. The latter shall indicate that there is the absence of a legitimate cause to the defendant's enrichment (Almășan \& Zamșa, 2015).

Belgian law contains no explicit statutory recognition of unjust enrichment (actio de in rem verso). Since the case decision on May 27, 1909, the highest court only refers to the theory as a general principle of law. Unjust enrichment which was often 


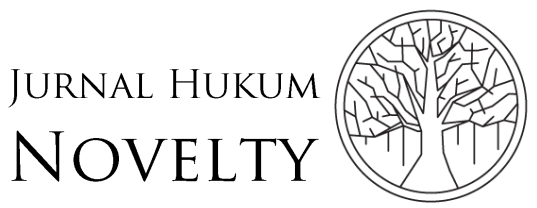

Volume 11, Issue 01, 2020, pp. 01-13
P-ISSN: $1412-6834$

E-ISSN: 2550-0090

referred to as "patrimonial shift without legal cause" is only available if the defendant has been enriched. This action requires the impoverishment of the claimant. Thus, the claimant shall prove the impoverishment by showing that he suffered a pecuniary valued disadvantage. Without such disadvantage, no action based on unjust enrichment is available under Belgian law. Even if there was remedial action based on unjust enrichment, the sum of disgorgement could never exceed the loss suffered; the claimant will receive no more than compensation. Here, the stressing point is the restoration of the claimant position prior to the suffered loss caused by the infringement of the defendant, not just the mere enrichment itself (Kruithof, 2015).

In China, the notion of disgorgement as gain-based damage was first introduced in China's Company Law. Later, it was expanded to several other areas of law, including intellectual property, torts, contract law, and securities. The provisions of disgorgement damage become an essential instrument for private relief and compensation practice in China (Gao \& Liu, 2015).

In China, three laws are providing the rules of disgorgement. First, the Securities Law of the People's Republic of China, which was promulgated in 1998 and amended in 2004,2005 , and 2013. There is only one article ruling on corporation disgorgement damage. Quoting article 42 of the Securities Law, it mentions as follow:

"Where any director, supervisor and senior manager of a listed company or any shareholder who holds more than $5 \%$ of the shares of a listed company, sell the stocks of the company as held within six months after purchase, or purchases any stock as sold within six months after that, any gains therefrom shall belong to the company. The board of directors of the company shall obtain the gains from these transactions for the company. However, where a securities company holds more than $5 \%$ of the shares of a listed company, which are the unsold stocks that the securities company has purchased from the company for resale, the sale of these stocks will not be limited by a term of 6 months. Where the board of directors of a company fails to implement the provisions as prescribed in the preceding paragraph herein, the shareholders concerned have the right to demand that the board of directors implement them within 30 days. Where the board of directors of a company fails to implement them within the aforesaid term, the shareholders have the right to directly file a lawsuit with the people's court in their names for the interests of the company. Where the board of directors of a company fails to implement the provisions as prescribed in paragraph one herein, the directors in charge shall be jointly and severally liable according to law."

The above provision governs that the majority shareholders' gains from "short swing trading" shall belong to the company.

Second, article 26 in the Trust Law of the People's Republic of China provides:

"the trustee must not take advantage of the trust property to seek profits for his own except getting remuneration according to the provisions of this law. If the trustee violates the provisions of the preceding paragraph to take advantage of the trust property to seek profits for his own, the profits he obtains shall be brought into the trust property."

Lastly, article 130 of Law of the People's Republic of China on Funds for Investment in Securities mentions:

"a fund management institution or fund custodian which commits any act as set out in items (1) to (5) and item (7), paragraph 1 of Article 74 of this Law or violates paragraph 2 of Article 74 of this Law shall be ordered to make rectification and be fined from 100,000 
Yuan up to one million Yuan; and the directly responsible person in charge and other directly liable persons shall be warned, with their fund business qualifications suspended or revoked, and be each fined from 30,000 Yuan up to 300,000 Yuan. Any property and income obtained from the utilization of fund assets by a fund management institution or fund custodian committing any act prescribed in the preceding paragraph shall become part of the fund assets, except as otherwise provided for by any law or administrative regulation" (Gao \& Liu, 2015).

As a follow up to the issuance of RPOJK on the Disgorgement and Disgorgement Fund, Indonesia needs to develop the theoretical framework to apply and enforce disgorgement of profit. The doctrine of actio(n) de in rem verso, or widely known as unjust enrichment in common law jurisdiction, might be the best start by referring to the Romanian system and Dutch Law in general.

The 0JK Regulation Draft is the first move to show the seriousness of investors' protection purposes by means of disgorgement and disgorgement fund. Even though there is still an absence of disgorgement legal basis in the act level in Indonesia, to anticipate and to avoid similar criticism in the Securities Law of the People's Republic of China, Indonesian concept of disgorgement fund to pay the investors' loss shall be maintained and strengthened. Article 209 of the Securities Law of People's Republic of China provides that, "all illegitimate incomes and fines lawfully confiscated and collected from issuing and trading securities against the law shall be delivered to the national treasury." Gao \& Liu (2015) asserted that the provision should be revised to be "illegitimate incomes confiscated shall be used to compensate for investors' loss." The same idea had been brought by OJK within the OJK Regulation Draft on Disgorgement and Disgorgement Fund. Indonesia, in the future, in general, may reflect from this disgorgement legal basis to cover not only within the context of the capital market but also in another area of law such as breach of contract, tort, intellectual property, and unfair competition.

\section{Imposition of Disgorgement}

The imposition of disgorgement shall be based on OJK's administrative decision in the form of Written Order. Technically, OJK has Internal Capital Market Investigator Team who is authorized to conduct an investigation. The investigation process will result in the Investigation Report being the legal basis of determining the loss suffered by the investors. OJK may block the Securities Account belongs to the disgorged Party, and the assets in the account may only be used to pay the disgorgement. If the disgorged Party ignored OJK's Written Order, then the Party might face the penal sanction (Mentari, 2019). Furthermore, the OJK Regulation Draft also provides that OJK may file a lawsuit or file a bankruptcy petition in case the disgorged Party does not pay the total amount of Disgorgement (OJK, 2019b).

Based on the Draft, the targets of disgorgement are those who conduct a violation of capital market regulation. Under 1995 Capital Market Law, there are three explicitly regulated primary criminal offenses which are disgorge able. First, the fraud under article 90; second, market manipulation subject to article 91 - 94; lastly, insider 


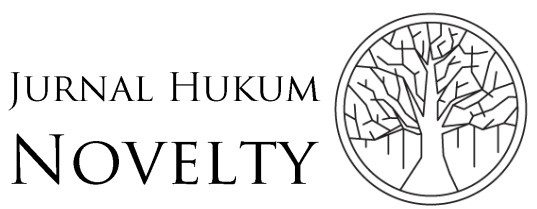

Volume 11, Issue 01, 2020, pp. 01-13
P-ISSN: $1412-6834$

E-ISSN: 2550-0090

trading under article 95 -99. In opposition to the criminal offenses, an administrative violation is questionable whether subject to disgorgement. In this case, Mentari asserted that administrative violations also subject to the disgorgement. The loss other than caused by criminal offenses or administrative violations is investment risk.

Further, she proposes three mechanisms in the claim of disgorgement. Firstly, as exofficio, on the ground of OJK's authority under article 9 letter d of OJK Act jo. Article 5 letter $\mathrm{n}$ of Capital Market Law, OJK can give an order of disgorgement payment. Secondly, individual claim to pay disgorgement of profits to be the anticipation of the feasible failure of OJK's disgorgement order. Thirdly, the class action of the loss investors (Mentari, 2019).

\section{Creating the Deterrence Effect from Disgorgement}

The issuance of OJK Regulation Draft on Disgorgement and Disgorgement Fund is firm on putting the notion of disgorgement both as the remedial action as well as to create a deterrence effect. Based on the United States jurisprudence for instance in SEC v. Fishbach Corp. (CA2 1997) and SEC v. First Jersey Securities, Inc. (CA2 1996), the primary aim of disgorgement is to deter violations the capital market regime by means of depriving violators of their illicit profits (Shah, 2019). Nonetheless, as previously discussed, in SEC v. Kokesh, the Supreme Court determined two cumulative legal tests of penalty-based sanction. The latter is that the purpose of the penalty is to give a deterrence effect. Further, the court concluded that SEC's disgorgement has a punitive purpose, which primarily aims to provide a deterrence effect, which is in opposition to compensation. Therefore, after the Supreme Court decision, blending the idea of remedy and deterrence effect is quite confusing. Consequently, it is essential first to find out how to create a deterrence effect.

International Organization of Securities Commissions (IOSCO) establishes rule proposals to achieve credible deterrence. Achievement of deterrence happens when the regulators (IOSCO, 2015):

1. demonstrate a willingness to impose or seek the imposition of sanctions and remedies that are effective, proportionate and dissuasive;

2. have at their disposal sanctions that appropriately respond to a wide range of evolving types of misconduct;

3. have access to an appropriate range of administrative and judicial avenues for the imposition of sanctions;

4. advocate that their administrative and judicial decision-makers be empowered with a suite of sanctioning powers and remedies that best address misconduct and the impact of that conduct;

5. hold individuals and entities, including those that are gatekeepers, such as accountants and lawyers, accountable;

6. seek practical and innovative sanctions and remedies that best serve the investors' and public interest;

7. in addition to pecuniary penalties and as appropriate, seek to recover the cost of their investigations, prosecutions, and litigation from those who burden society with their illicit and unethical practices. 
In brief, regulators shall have and willingly use a range of sanctions that are effective, proportionate and dissuasive. The penalties should be more severe than the cost of the misconduct. An intense punishment will stress a point on there shall be no profit from misconduct.

The France Monetary and Financial Code (L'Autorité des Marchés Financiers) provide the best model. In the subject of insider trading criminal offenses, article L465-1 governs for a fine of 1.5 million Euros, "which amount may be increased to a figure representing up to ten times the amount of any profit realized and shall never be less than the amount of said profit." The measure enables the claimant to seek disgorgement that is ten times from the profit-gained or loss avoided. The means indeed greatly exceed the objective of disgorgement of illicit profits as it also gives the punishment to the responsible Party (Séjean, 2015).

Another decent example is a new 2010 penalties regime for misconduct in the United Kingdom. IOSCO report asserted that the new arrangement was to create transparency of means in setting up the penalties, improve the consistency of penalties levied as well as achieving credible deterrence by enhancing the levels of penalties. The regime focusses on three principles: “(i) disgorgement of profits made or losses avoided, (ii) discipline taking into account the seriousness, nature and impact of the breach and any aggravating or mitigating factors, and (iii) deterrence to the subject and the market" (IOSCO, 2015).

\section{Conclusion}

The disgorgement as a new means, indeed, aims to enhance investors' protection from the loss suffered due to the violation of capital market regulation. In its upcoming technical manner, OJK will give a written order for the Party who violates capital market regulation and pursuing illegally obtained profit or illegally avoided loss to return the sum amount of money as so-called disgorgement sum up with interest (if any). To uphold this scheme, Indonesia needs to develop the theoretical framework prior to applying the disgorgement as the remedial action, which also aimed to create a deterrence effect. Learning from the SEC v. Kokesh in the US, the notion of "remedial action" itself shall be clear at the very first place to diminish an ambiguity. Research of actio de in rem verso or unjust enrichment sound to be a good start to strengthening the disgorgement rules fully.

Furthermore, to create a deterrence effect, the IOSO proposal is a virtuous considerable. The sanction shall be effective, proportionate, and dissuasive. France Monetary and Financial Code might be a good model. The measure to seek disgorgement to ten times the profit made or loss avoided aims to disgorging illicit profit and also providing punishment to create credible deterrence. Nonetheless, the issuance of the 0JK Draft Regulation on Disgorgement and Disgorgement Fund in Capital Market probably becomes a worthy initial move to protect the investor from suffering the loss. 


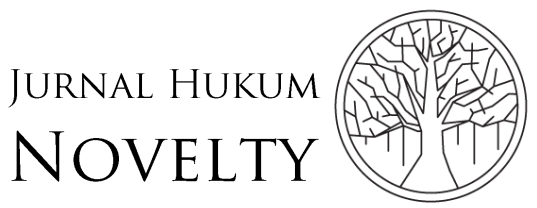

Volume 11, Issue 01, 2020, pp. 01-13
P-ISSN: $1412-6834$

E-ISSN: 2550-0090

\section{References}

Akbar, M. F. (2016). Kondisi masyarakat berisiko di Desa Sungai Buluh Kabupaten Lingga (Universitas Maritim Raja Ali Haji). Retrieved from http://jurnal.umrah.ac.id/wp-content/uploads/gravity_forms/1ec61c9cb232a03a96d0947c6478e525e/2016/08/E-JURNAL6.pdf

Almășan, A., \& Zamșa, C. (2015). Legal mechanisms enabling disgorgement of profits in Romania. In E. Hondius \& A. Janssen (Eds.), Disgorgement of Profits (8th ed., pp. 187-198). https://doi.org/10.1007/978-3-319-18759-4

Boyd, W., Beck, U., \& Shrader-Frechette, K. S. (1993). Risk society: Towards a new modernity. Economic Geography, 69(4), 432. https://doi.org/10.2307/143601

Danneman, G. (2009). The German law of unjustified enrichment and restitution: $A$ comparative introduction. New York: Oxford University Press.

Gao, X., \& Liu, C. (2015). The disgorgement damage system in Chinese law. In E. Hondius \& A. Janssen (Eds.), Disgorgement of Profits (8th ed., pp. 407-428). https://doi.org/10.1007/978-3-319-18759-4_22

Garner, B. A. (2009). Black's law dictionary (9th Edition). West Publishing Co. Thomson Reuters.

Giglio, F. (2001). Restitution for wrongs: a Comparative analysis. Retrieved December 30, 2019, from http://ouclf.law.ox.ac.uk/restitution-for-wrongs-a-comparativeanalysis/

Putranto, H. (2017). Menyoal risiko dan kontingensi pengetahuan dalam masyarakat pengetahuan kontemporer. An1mage Jurnal Studi Kultural, 2(1), 55-69. Retrieved from https://journals.an1mage.net/index.php/ajsk/article/view/79

Hondius, E., \& Janssen, A. (2015a). Disgorgement of profits: Gain-based remedies throughout the world. In E. Hondius \& A. Janssen (Eds.), Disgorgement of Profits (8th ed., pp. 115-134). https://doi.org/10.1007/978-94-024-1066-2_6

Hondius, E., \& Janssen, A. (2015b). Original questionnaire: Disgorgement of profits. In E. Hondius \& A. Janssen (Eds.), Disgorgement of Profits (8th ed.). https://doi.org/10.1007/978-3-319-18759-4

IOSCO. (2015). Credible deterrence in the enforcement of securities regulation. Retrieved January 24, 2020, from https://www.rimes.com/insights/ioscocredible-deterrence-in-the-enforcement-of-securities-regulation/

Karmel, R. (2018). Will fifty years of the SEC's disgorgement remedy be abolished? SMU Law Review, 71(3), 799-810. Retrieved from https://scholar.smu.edu/cgi/viewcontent.cgi?article=4748\&context=smulr

Kirk, J. T. (2015). Deranged disgorgement. The Journal of Business, Enterpreneurship \& the Law, 8(1), 133-187. Retrieved from https://bit.ly/2Uvpp8s

Kruithof, M. (2015). Disgorgement of profits in Belgian private law. In E. Hondius \& A. Janssen (Eds.), Disgorgement of Profits (8th ed., pp. 89-120). https://doi.org/10.1007/978-3-319-18759-4_5

Latham, \& Watkins. (2017). US supreme court: Disgorgement is a penalty, limiting SEC's reach the supreme court's decision (pp. 1-4). pp. 1-4.

Linssen, J. G. A. (2001). Voordeelsafgifte en ongerechtvaardigde verrijking: (Een rechtsvergelijkende beschouwing). Den Haag: Boom Juridische Uitgevers.

Mentari, N. (2019). Pemberian ganti rugi investor di pasar modal melalui disgorgement fund. Universitas Airlangga. 
Muklis, F. (2016). Perkembangan dan tantangan pasar modal Indonesia. Al Masraf (Jurnal Lembaga Keuangan Dan Perbankan), 1(1), 1-12.

OJK. (2017). Pengumuman: Sanksi administratif kepada pihak-pihak yang terlibat dalam kasus pelanggaran peraturan perundang-undangan di bidang pasar modal oleh Sdri. Esther Pauli Larasati, PT Reliance Securities Tbk, PT Magnus Capital dan pihak terkait. Retrieved December 30, 2019, from https://www.ojk.go.id/id/berita-dan-

kegiatan/pengumuman/Documents/Pengumuman.pdf

OJK. (2019a). Permintaan tanggapan masyarakat atas RPOJK tentang disgorgement dan disgorgement fund di bidang pasar modal. Retrieved December 30, 2019, from https://www.ojk.go.id/id/regulasi/otoritas-jasa-keuangan/rancanganregulasi/Pages/Permintaan-Tanggapan-Masyarakat-atas-RPOJK-tentang-Disgorgement-dan-Disgorgement-Fund-di-Bidang-Pasar-Modal.aspx

OJK. Rancangan peraturan otoritas jasa keuangan tentang disgorgement dan disgorgement fund di bidang pasar modal. , March § (2019).

OJK. (2019b). Statistik mingguan, Desember minggu ke-4, 2019. Retrieved from https://www.ojk.go.id/id/kanal/pasar-modal/data-dan-statistik/statistik-

pasar-modal/Documents/4. Statistik Desember Mgg ke-4 2019.pdf\#search=Statistik mingguan\%2C Desember minggu ke-4\%2C 2019

Ryan, R. G. (2013). The equity façade of SEC disgorgement. Harvard Business Law Review Online, 4, 1-14. Retrieved from https://heinonline.org/HOL/LandingPage?handle=hein.journals/hblro4\&div= 2\&id=\&page $=$

Schauer, M., \& Verschraegen, B. (2017). General Reports of the XIXth Congress of the International Academy of Comparative Law Rapports Généraux du XIXème Congrès de l'Académie Internationale de Droit Comparé (M. Schauer \& B. Verschraegen, Eds.). https://doi.org/10.1007/978-94-024-1066-2

Séjean, M. (2015). The disgorgement of illicit profits in French law. In E. Hondius \& A. Janssen (Eds.), Disgorgement of Profits: Gain-Based Remedies Throughout the World (8th ed., pp. 121-137). https://doi.org/10.1007/978-3-319-18759-4_6

Shah, V. (2019). Determining disgorgement in securities law. The Law Review, Government Law College, 10, 138-173. Retrieved from http://www.glcmumbai.com/lawreview/volume10/Vidhi\%20Shah.pdf

Shipman, B. J. (1923). Handbook of Common-Law Pleading (3rd ed.; H. W. Ballantin, Ed.). St. Paul: West Publishing Company.

Sianipar, B. D. (2019). Peran pemerintah dalam mitigasi kejahatan pasar modal. Journal of Education, Humaniora and Social Sciences (JEHSS), 2(1), 104-118. https://doi.org/10.34007/jehss.v2i1.68

Tari, D. N. (2019). OJK mulai racik revisi UU pasar modal. Retrieved December 30, 2019, from https://market.bisnis.com/read/20191101/7/1165719/ojk-mulairacik-revisi-uu-pasar-modal

Tri, R. (2020). Skandal jiwasraya dan dugaan praktik Manipulasi di pasar modal. Retrieved January 24, 2020, from https://bisnis.tempo.co/read/1299186/skandal-jiwasraya-dan-dugaanpraktik-manipulasi-di-pasar-modal 